\title{
Vertical distribution of available macro and micronutrients in soil profiles of Ganapavaram pilot area of Nagarjuna Sagar left canal command area of Andhra Pradesh
}

\section{RAJESHWAR AND V. RAMULU}

Received : 16.12.2015; Revised : 21.04.2016; Accepted : 17.05.2016

MEMBERS OF RESEARCH FORUM:
Corresponding author :
M. RAJESHWAR, Agricultural
Research Station (ANGRAU),
GARIKAPADU, KRISHNA (A.P.)

Co-authors :

V. RAMULU, Agricultural Research Station (ANGRAU), GARIKAPADU, KRISHNA (A.P.)

\section{Summary}

Studies undertaken to assess the nutrient status of soils of pilot area Ganapavaram of $24 \mathrm{~L}$ Minor and Muktheswara Puram Major of Nagarjuna Sagar Project left canal command of Nalgonda district of Andhra Pradesh have been studied. Profile wise nutrient status in soil profiles of pilot area revealed that the soils were low to medium in available nitrogen (94 - 219 $\mathrm{kg} \mathrm{ha}^{-1}$ ), low to high in available phosphorus ( 4.4 to $45.5 \mathrm{~kg} \mathrm{ha}^{-1}$ ) and low to high in available potassium (98 to $482 \mathrm{~kg} \mathrm{ha}^{-1}$ ). The DTPA extractable available micronutrients $\mathrm{Zn}, \mathrm{Cu}, \mathrm{Mn}$ and Fe ranged from 0.24 to $2.52 \mathrm{mg} \mathrm{kg}^{-1}, 1.20$ to $4.59 \mathrm{mg} \mathrm{kg}^{-1}, 1.18$ to $15.65 \mathrm{mg} \mathrm{kg}^{-1}$ and 1.67 to 49.1 $\mathrm{mg} \mathrm{kg}^{-1}$ soil, respectively. Soils were low to medium in available nitrogen, high in available phosphorus and medium to high available potassium in the surface horizons and in case of available micronutrients deficient to sufficient in $\mathrm{Zn}$ and sufficient in available $\mathrm{Cu}, \mathrm{Fe}$ and $\mathrm{Mn}$ in the surface layers of the soil profiles.

Key words : Available N, P, K, Available micronutrients

How to cite this article : Rajeshwar, M. and Ramulu, V. (2016). Vertical distribution of available macro and micronutrients in soil profiles of Ganapavaram pilot area of Nagarjuna Sagar left canal command area of Andhra Pradesh. Asian J. Soil Sci., 11 (1) : 202-206 : DOI : 10.15740/HAS/AJSS/11.1/202-206. 